\title{
Virilisation due to a Leydig cell tumor of the ovary - diagnostic and therapeutic challenges
}

Ruxandra Dobrescu ${ }^{1}$, Cristian Poalelungi ${ }^{3}$, Iuliana Ceausu ${ }^{2,3}$, Dan Hortopan ${ }^{1}$, Corin Badiu ${ }^{1,2}$

1. "C.I.Parhon" National institute of Endocrinology, Bucharest, Romania

2. "Carol Davila" University of Medicine and Pharmacy, Bucharest, Romania

3. „Dr I. Cantacuzino” Clinical Hospital - Department of Obstetrics and Gynecology II

\section{Introduction}

- Frequently encountered in clinical practice (5-10\% of women of childbearing age), hirsutism is most often due to polycystic ovary syndrome or it is idiopathic. However rarer causes should be taken into account, such as drugs, congenital adrenal hyperplasia, ovarian hyperthecosis, severe insulin resistance or Cushing's syndrome.

- Severe hirsutism and virilisation, especially if occurring later in life and with rapid onset, should prompt the search for rare but potentially threatening causes such as androgen secreting ovarian or adrenal tumour.

\section{Presentation}

- We present the case of PC, 47 years old, who presented to the endocrinology clinic for the investigation of severe hirsutism. At examination she was also found to be obese, with alopecia, acne and deepening of the voice that she declared had appeared insidiously 2 years ago. Although bothersome, she thought these to be a delayed effect of hormonal treatment for fertility during her youth (she was unable to give details).

- She declared irregular menstrual periods throughout her life and amenorrhea for the past 2 years, which she interpreted as menopause.

\section{Laboratory evaluation}

Haematology and biochemical testing: polycythemia (Haemoglobin= $16.3 \mathrm{~g} / \mathrm{dl}$, Haematocrit $=49.3 \%$ ) and impaired glucose tolerance.

Hirsutism and virilisation:

- IGF1 and 170Hprogesterone were normal, excluding acromegaly and congenital adrenal hyperplasia.

- Baseline ACTH, cortisol and DHEAS levels were normal, with adequate suppression of cortisol after low dose $(2 \times 2 \mathrm{mg})$ Dexamethasone suppression testing (LDDST) excluding an adrenal hypersecretion.
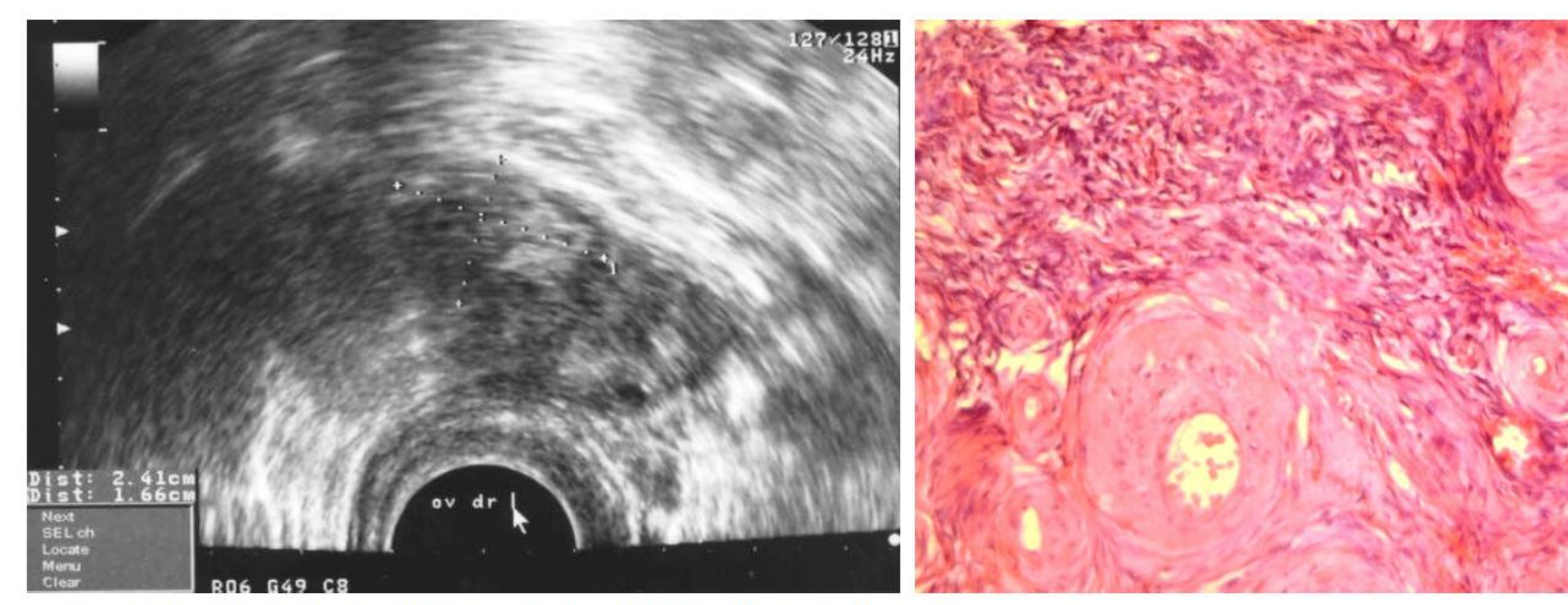

Figure 2. A. Abdominal ultrasound $-\mathrm{a} 2.41 / 1.66 \mathrm{~cm}$ right ovarian mass.

B. Highly vascular ovarian stroma with fragment from a Leydig cell tumor (HE stain, X400)

\section{Treatment}

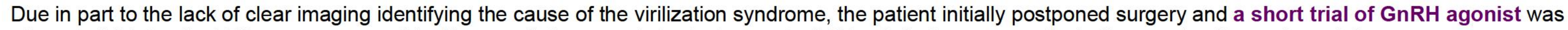
attempted (triptorelin $3.75 \mathrm{mg} \mathrm{sc}$ per month) with a small decrease in testosterone to $5.65 \mathrm{ng} / \mathrm{ml}$ after one month, further proving its ovarian origin.

A repeat ultrasound was performed, showing a $2.41 / 1.65 \mathrm{~cm}$ mass in the right ovary, suggesting an androgen-secreting ovarian tumor.

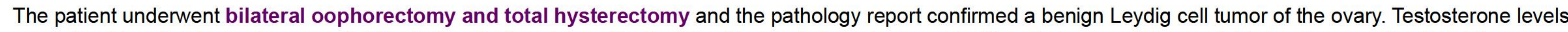
normalized imediately post-surgery $(0.30 \mathrm{ng} / \mathrm{ml})$ and after six months the hirsutism and alopecia were significantly improved, hemoglobin levels normalized, but the obesity persisted and diabetes mellitus was diagnosed.

\begin{tabular}{|c|c|c|c|c|c|c|c|}
\hline & $\begin{array}{c}\text { Baseline } \\
\text { (feb 2013) }\end{array}$ & $\begin{array}{c}\text { Midnight } \\
\text { (feb 2013) }\end{array}$ & $\begin{array}{c}\text { LDDST } \\
\text { (feb 2013) }\end{array}$ & \multirow{8}{*}{$\begin{array}{c}\text { After } 1 \\
\text { month of } \\
\text { treatment } \\
\text { with } \\
\text { Triptorelin } \\
3.75 \mathrm{mg}\end{array}$} & $\begin{array}{l}\text { Apr } \\
2014\end{array}$ & \multirow{8}{*}{$\begin{array}{l}\text { After bilateral } \\
\text { oophorectomy }\end{array}$} & $\begin{array}{l}\text { Feb } \\
2014\end{array}$ \\
\hline ACTH (pg/ml) & 33.85 & - & - & & & & 8.53 \\
\hline Cortisol (ug/dl) & 10.08 & 1.6 & 0.76 & & & & 9.77 \\
\hline DHEAS (ug/dl) & 306.8 & - & 113.7 & & & & 191.5 \\
\hline $\begin{array}{c}\text { Testosterone } \\
\text { (ng/ml) }\end{array}$ & 6.38 & - & 7.57 & & 5.65 & & 0.33 \\
\hline LH (mUl/ml) & 2.63 & - & - & & & & 12.81 \\
\hline FSH (mUl/ml) & 5.59 & - & - & & & & 27.07 \\
\hline Estradiol (pg/ml) & 86 & - & - & & & & $<20$ \\
\hline
\end{tabular}

Insulin resistance and Diabetes Mellitus Although hyperandrogenism is known to exacerbate insulin resistance (through mechanisms that are still not well defined), in this patient the progression of the impaired glucose tolerance to diabetes mellitus, in the setting of the remission of hyperandrogenism and the presence of obesity, points toward a type 2 DM.

\section{Conclusion:}

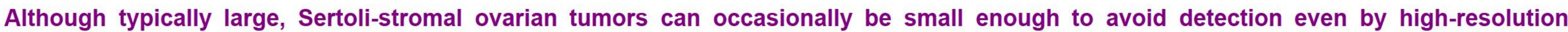

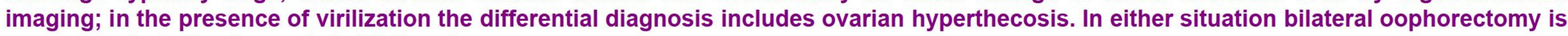
recommended after the end of childbearing years.
- Ovarian sex cord-stromal tumors are rare neoplasms ( $1 \%$ of ovarian neoplasms) that develop from the stem cells that would normally generate the

- are usually unilateral and large $(>10 \mathrm{~cm})$ unless discovered incidentally

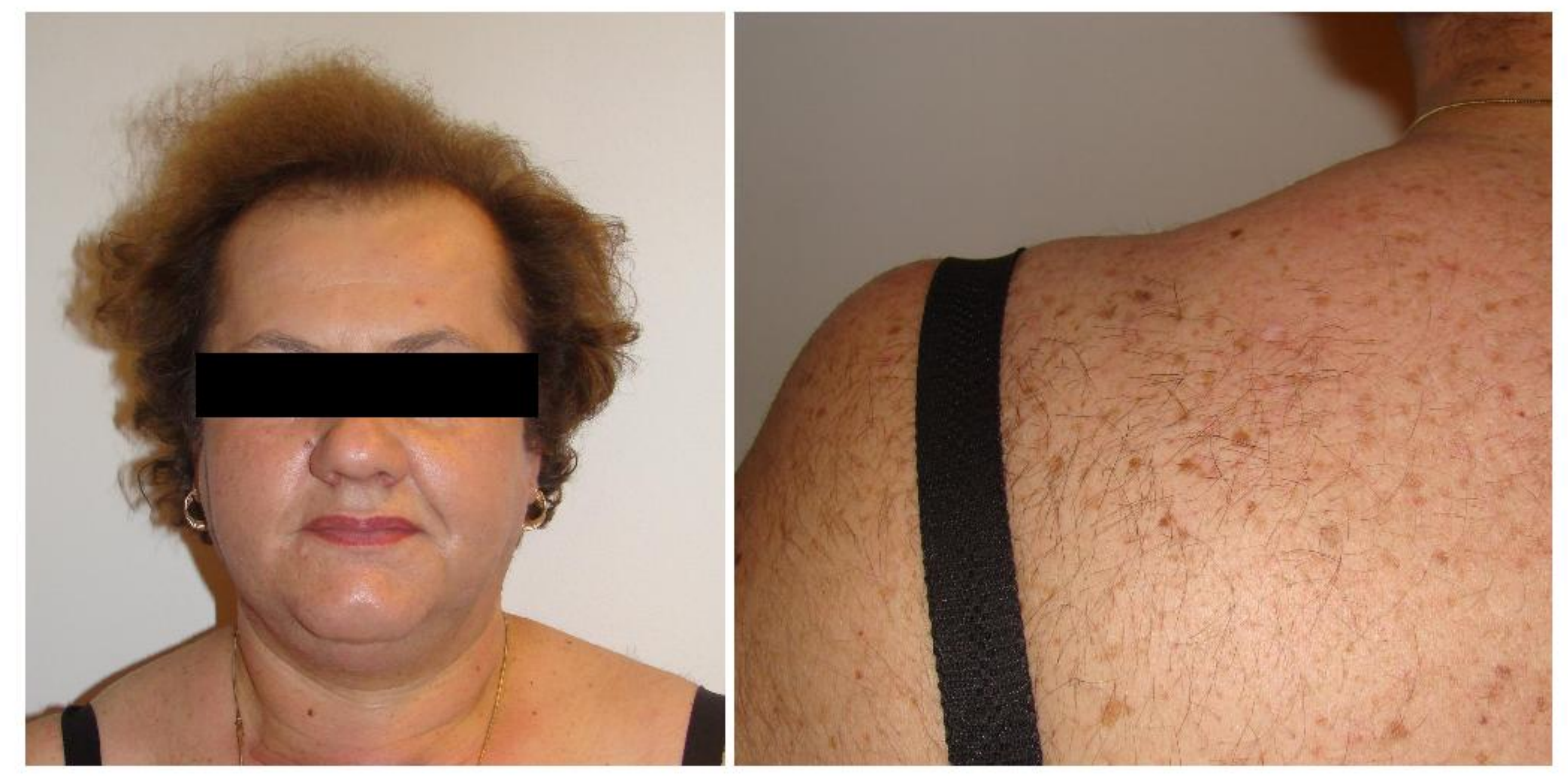

- She had severe hyperandrogenism - total testosterone $=6.38 \mathrm{ng} / \mathrm{ml}$ which increased paradoxically after LDDST $(7.57 \mathrm{ng} / \mathrm{ml})$

$\mathrm{mUl} / \mathrm{ml}$, estradiol $=86 \mathrm{pg} / \mathrm{ml}$ ) reflecting either androgen induced amenorrhea in premenopause, or testosterone mediated gonadotropin

CT scans of the abdomen and pelvis and the ultrasound evaluation of the uterus and ovaries showed normal morphology - raising suspicion of ovarian hyperthecosis.

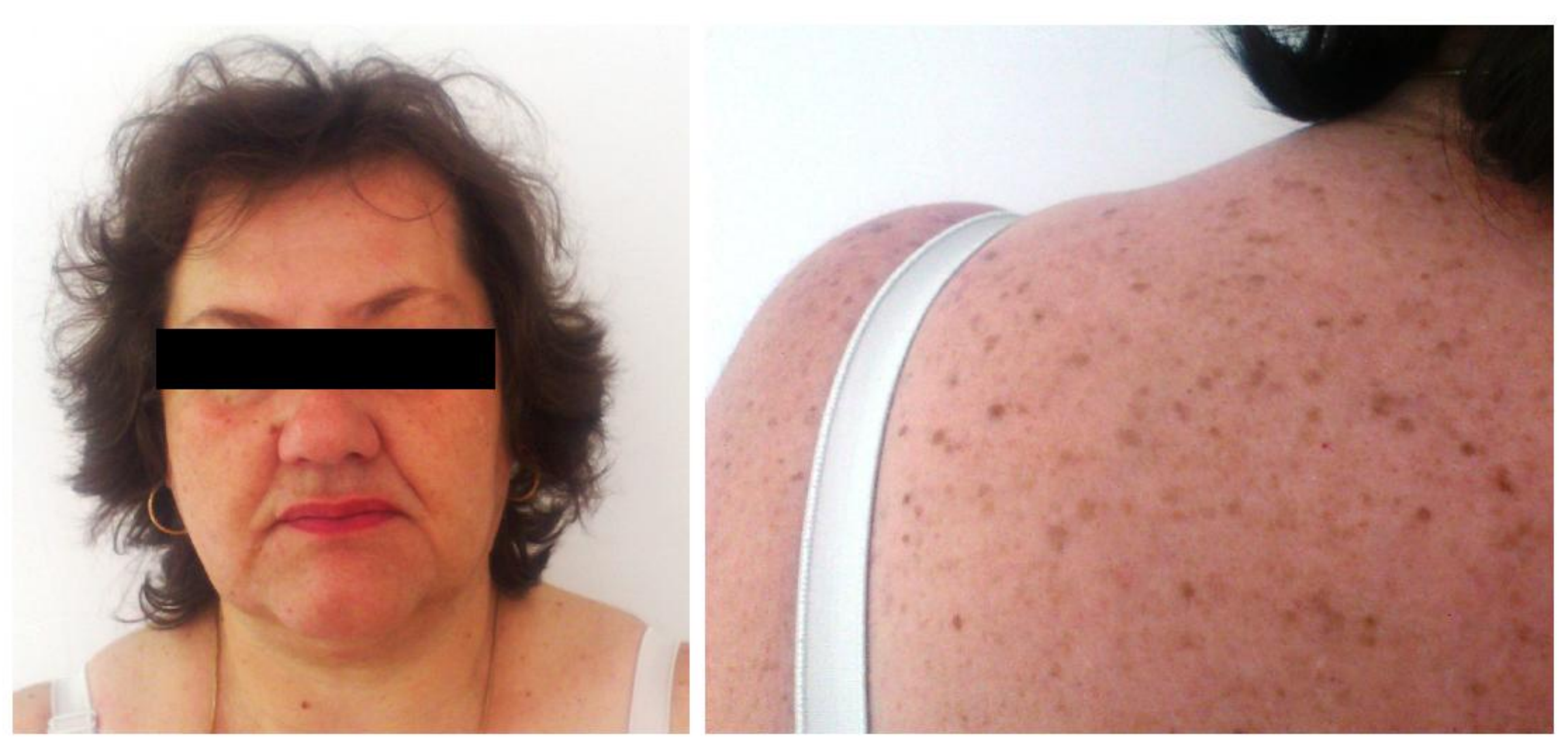

Figure 3. May 2015: Regression of alopecia, and marked improvement of hirsutism androgens and androgen precursors leading to severe hirsutism. 